Available online on 15.01.2018 at http://ujpr.org
Universal Journal of Pharmaceutical Research
An International Peer Reviewed Journal
Open access to Pharmaceutical research

\title{
EXTRACTION AND PHYSICOCHEMICAL CHARACTERIZATION OF NOVEL POTENT MUCOADHESIVE BIO-MATERIAL OBTAINED FROM THE FRESH FRUITS PULP OF ACHRAS ZAPOTILLA \\ Arun Kumar Singh $^{1}\left(\mathbb{D}\right.$, Anita Singh ${ }^{2}\left(\mathbb{D}\right.$, NV Satheesh Madhav $^{3}(\mathbb{D}$ \\ ${ }^{I}$ Devsthali Vidyapeeth Collge of Pharmacy, Rudrapur, Uttarakhand, India. \\ ${ }^{2}$ Department Of Pharmaceutical Sciences Bhimtal Campus,Kumaun University, Nainital Uttarakhand, India. ${ }^{3}$ DIT University, Faculty of Pharmacy, Mussoorie Diversion Road, Dehradun, Uttarakhand, India.
}

\section{ABSTRACT}

Objectives: The objective of present investigation was to isolate an effective novel mucoadhesive biomaterial from the pulp of Achras zapotilla, belonging to Sapotaceae family. In the recent years the research in the biomaterial isolation and their use as pharmaceutical excipients become a core area for formulation scientist to develop safe and effective drug delivery system.

Methods: The biomaterial was isolated by simplified economical method and was subjected to phytochemical, physicochemical, micromeritic as well as spectral analyses like IR, 1HNMR, DSC, SEM and Elemental analysis. The mucoadhesive property of the biomaterial was assessed by shear stress method, falling sphere method and rotating cylinder method using nasal mucosa as substrates.

Results: The results were compared with HPMC and sodium CMC as a standard. The formation of hydrogen bond by natural mucoadhesive agent with mucosa was confirmed by FTIR spectra showing carboxyl and hydroxyl groups.

Conclusion: The research study revealed that the biomaterial obtained from fruit pulp of Acarus zapotila exhibited a promising potent natural mucoadhesive property and may be used to develop mucoadhesive transmucosal drug delivery systems.

Keywords: Achras zapotilla, mucoadhesive property, Nasal mucosa, shear stress testing, thermal analysis.

Article Info: Received 4 November 2017; Revised 2 December; Accepted 27 December, Available online 15 January 2018

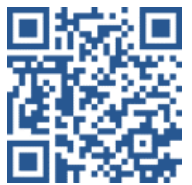
Cite this article-

Singh AK, Singh A, Madhav NVS. Extraction and physicochemical characterization of novel potent mucoadhesive bio-material obtained from the fresh fruits pulp of Achras zapotilla. Universal Journal of Pharmaceutical Research 2017; 2(6): 24-31.

DOI: http://doi.org/10.22270/ujpr.v2i6.R6

Address for Correspondence:

Arun Kumar Singh, Devsthli Vidyapeeth College of Pharmacy, Rudrapur, Uttarakhand, India. Mobile-+91-9568084835, E-mail: arunsinghpharma@gmail.com

\section{INTRODUCTION}

Pharmaceutical drug delivery system the excipients play a vital role in the development of dosage forms, suitable for administration to patients. In recent years, excipients development is become core area of research in pharmaceutical drug delivery because it influences the formulation development and drug delivery process in various ways. Biomaterials are choice of research as excipients because of its low cost, nontoxic, relatively wide spread availability, biocompatible, biodegradable, better patient compliance, eco -friendly, renewable in nature and acceptable by the regulating authorities compared to their synthetic counterparts ${ }^{1}$. Mucoadhesion, an interfacial phenomenon based on two materials, one of which is mucus layer of mucosal tissue, to which the drug is held together by means of interfacial forces for prolonged period of time ${ }^{2}$. The formation of hydrogen bond by natural mucoadhesive agent with mucosa was confirmed by FTIR spectra showing carboxyl and hydroxyl groups ${ }^{3}$. In the recent years the interest is growing to develop a drug delivery system with the use of mucoadhesive polymer that will attach to the relative tissue for the targeting various absorptive surface mucosa such as nasal, ocular, pulmonary, buccal, vaginal etc $^{4}$. The objective of this study is to isolate the biomaterial from the fruit pulp of A. zapotilla and to determine its intrinsic mucoadhesive property.

\section{MATERIALS AND METHODS}

A. zapotilla fruit was obtained from the local market Haldwani, Nainital, Uttarakhand and were authenticated from Department of biotechnology Devsthali Vidyapeeth Rudrapur. Sodium CMC and HPMC and Acetone was purchased from S D Fine chemicals. Double distilled water was prepared from 
the institutional laboratory. All other chemicals used were of analytical grade and were freshly prepared. Extraction of mucoadhesive biomaterial

A. zapotilla fruit pulp was collected after removing the upper most layer as well as seeds and minced with sufficient quantity of water. It was filtered with muslin cloth and filtrate was centrifuged at $3000 \mathrm{rpm}$ for 10 min., the supernatant was collected, filtered and treated with methanol to extract the biomaterial.

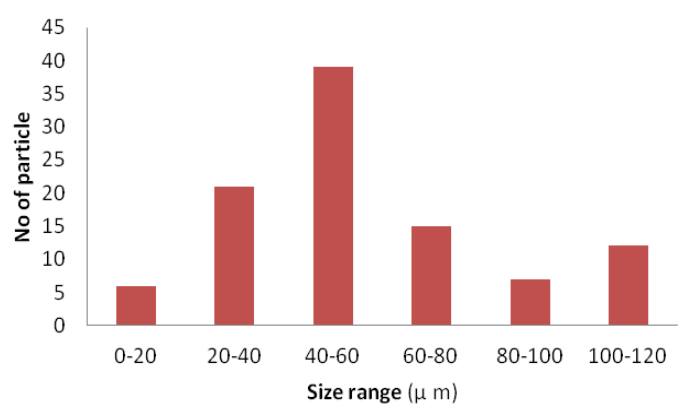

Figure 1: Graphical representation of particle size distribution of $A$. zapotilla biomaterial.

The extracted biomaterial was washed repeatedly with methanol, collected, purified by dialysis method and dried at $50-60^{\circ} \mathrm{C}$ under vacuum for $12 \mathrm{~h}$. The dried biomaterial was pulverized and passed through 120 mesh sieve to get uniform size particles and stored in desiccators till further use. Percentage yield of isolated biomaterial was calculated. The percentage yield of isolated biomaterial was calculated ${ }^{5,6}$.

Table 1: Physicochemical property of $A$. zapotilla biomaterial.

\begin{tabular}{ll}
\hline Property & Results \\
\hline Bulk density $(\mathrm{g} / \mathrm{cc})$ & 0.76 \\
Tapped density $(\mathrm{g} / \mathrm{cc})$ & $0 . .89$ \\
True density $(\mathrm{g} / \mathrm{cc}) 0.5 \% \mathrm{~W} / \mathrm{v}$ & 2.52 \\
solution & \\
Angle of repose & 27.23 \\
Compressibility index (\%) & 15 \\
Hausner Ratio & 1.17 \\
$\mathrm{pH}(1 \%$ w/v solution) & $5.5 \pm 0.010$ \\
Swelling index (\%) in DW & $19 \pm 0.23$ \\
Viscosity (1\%w/v solution) & $1.028 \mathrm{cp}$ \\
Color Change Temperature & $122-124^{0} \mathrm{C}$ \\
Loss on drying \% & 4.3 \\
\hline
\end{tabular}

Physicochemical characterization of biomaterial

The dried biomaterial was studied for percentage yield, appearance, solubility, viscosity, $\mathrm{pH}$, swelling index, and bulk and tapped densities, angle of repose, compression properties.

\section{Percentage yield}

The percentage yield of biomaterial was calculated on the amount of fruit pulp used for extraction process and amount of dry powder obtains individually depend upon solvents used ${ }^{7}$. The percentage yield was calculated using the formula mentioned below,

$$
\text { Percentage yield }=\frac{\text { Wt of dried biomaterial obtained }}{\text { Wt of leaves powder taken }} \times 100
$$

\section{Organoleptic evaluation}

The organoleptic evaluation refers to the evaluation of color, odor, shape, taste and special features which include touch and texture. The majority of information on the identity, purity and quality of the material can be drawn from these observations ${ }^{8}$ (Table 2 ).

Table 2: Organoleptic evaluation of selected polysaccharide.

\begin{tabular}{lc}
\hline Parameter & A. zapotilla biomaterial \\
\hline Color & Light brown \\
Odour & Odourless \\
Taste & Tasteless \\
Shape & Irregular \\
Appearance & Amorphous \\
Nature & Powder \\
\hline
\end{tabular}

\section{Solubility}

The Solubility of biomaterial was determined in different common solvents (Table 3).

Table 3: Solubility behavior of the biomaterial.

\begin{tabular}{lc}
\hline Solvent use & Solubility behaviour \\
\hline Cold water $(8-$ & Sparingly soluble \\
$\left.25^{\circ} \mathrm{c}\right)$ & \\
Warm water $(35-$ & $\begin{array}{c}\text { Soluble forming a } \\
\text { viscous colloidal } \\
\left.40^{\circ} \mathrm{c}\right)\end{array}$ \\
& solution \\
Ethanol & Insoluble \\
Methanol & Insoluble \\
Acetone & Insoluble \\
Ether & Insoluble \\
Cyclohexane & Insoluble \\
Chloroform & Insoluble \\
Benzene & Insoluble \\
\hline
\end{tabular}

\section{Loss on drying}

Weight loss on drying was determined for an appropriate quantity of biomaterial at $105^{\circ} \mathrm{C}$ for two hours and percentage loss of moisture on drying was calculated using formula ${ }^{9}$ (Table 1).

$$
\text { LOD }(\%)=\frac{\text { Weight of water in sample }}{\text { Weight of dry sample }} \times 100
$$

Determination of $\mathrm{pH}$ of the polymer

The $\mathrm{pH}$ of $1 \%$ solution of the biomaterial was determined using a digital $\mathrm{pH}$ meter.

Density

A $0.5 \% \mathrm{w} / \mathrm{v}$ solution of dried mucilage was prepared and transferred to a density measurable bottle. An empty bottle with distilled water was weighed. The density of the dried mucilage was calculated ${ }^{10}$.

\section{Swelling index}

The Swelling index is the volume in ml occupied by $1 \mathrm{~g}$ of the substance. The Swelling index of the mucilage powder was determined by according to British Pharmacopoeia. One gram of biomaterial powder was accurately weighed and transferred to a $100 \mathrm{ml}$ stoppered measuring cylinder. The initial volume of the powder in the measuring cylinder was noted. The volume was made up to $100 \mathrm{ml}$ mark with distilled water. The cylinder was stoppered, shaken gently and set aside for $24 \mathrm{~h}$. The volume occupied by the gum sediment was noted after $24 \mathrm{~h}^{11}$ (Table 1). 
The swelling ratio was calculated by determining the ratio of swollen volume to the initial bulk Volume using the formula.

$$
\mathrm{s}=\frac{\mathrm{V} 2-\mathrm{V} 1}{\mathrm{~V} 1}
$$

Where;

$\mathrm{S}=$ swelling index

$\mathrm{V}_{1}$ =volume occupied by the biomaterial prior to hydration

$\mathrm{V}_{2}$ =volume occupied by the biomaterial after hydration.

Table 4: Particle size distribution of A. zapotilla biomaterial.

\begin{tabular}{cc}
\hline Size range $(\boldsymbol{\mu} \mathbf{~ m})$ & $\begin{array}{c}\text { Number of } \\
\text { particles }\end{array}$ \\
\hline $0-20$ & 6 \\
$20-40$ & 21 \\
$40-60$ & 39 \\
$60-80$ & 15 \\
$80-100$ & 7 \\
$100-120$ & 12 \\
\hline
\end{tabular}

Determination of particle size distribution

Biomaterial was sprinkled on glass slide containing Glycerin and examined through using calibrated eye piece micrometer under microscope. About 100 particles size were counted in different fields and particle size distribution of mucilage shown in Figure 1 , the particle size distribution result is mentioned in Table 4.

Table 5: Ash Values of A. zapotilla Biomaterial.

\begin{tabular}{ll}
\hline Types of Ash & $\begin{array}{l}\text { Ash Value in } \\
\text { \%w/w }\end{array}$ \\
\hline Total ash & $4.9 \%$ \\
Acid insoluble ash & $0.48 \%$ \\
Water soluble ash & $4.3 \%$ \\
\hline
\end{tabular}

Bulk and tapped density

A pre weighed quantity of dried mucilage was poured into a graduated cylinder, and the volume recorded. The bulk density was obtained by dividing the weight of the sample by volume of the sample contained in the cylinder. Tapped density of biomaterial was determined by USP-II method and it is the ratio of weight of dry powder to its tapped volume (Table 1). The volume of powdered bed is measured after each increment of 250 drops until the difference of last two volume measurement is zero ${ }^{11}$. The bulk and tapped densities were calculated using the formula-

$$
\begin{aligned}
& \text { Bulk density }=\frac{\text { Mass of biomaterial }}{\text { Bulk volume }} \\
& \text { Tapped density }=\frac{\text { Mass of biomaterial }}{\text { Tapped volume }}
\end{aligned}
$$

\section{Angle of repose}

The angle of repose was determined by the fixed height funnel method. The dried biomaterial powder was carefully poured through the funnel until the apex of the conical pile just touched the tip of the funnel. The maximum cone height (h) of the pile and radius ( $r$ ) of the base of the pile was determined and angle of repose was calculated ${ }^{12}$.
Angle of repose $\tan \theta=\frac{h}{r}$

Carr's Index and Hausner's Ratio:

Carr's index and Hausner's ratio were calculated from the bulk and tapped densities using the formula-

$$
\begin{gathered}
\text { Carr's Index }=\frac{\text { Tapped density }- \text { fluff density }}{\text { Tapped density }} \times 100 \\
\text { Hausner's ratio }=\frac{\text { Tapped density }}{\text { bulk density }}
\end{gathered}
$$

\begin{tabular}{|c|c|}
\hline Test & Result \\
\hline \multicolumn{2}{|l|}{ Test for alkaloids } \\
\hline Wagner's test & - \\
\hline Mayer test & - \\
\hline Dragendroff test & - \\
\hline Test for Carbohydrates (Molisch's test) & + \\
\hline Test for saponin (foam test) & + \\
\hline Test for proteins Ninhydrin test & - \\
\hline Biuret test & - \\
\hline \multirow{2}{*}{$\begin{aligned} \text { Test for Tannins } & \text { (Ferric chloride test) } \\
& \text { (Aquous bromine test) }\end{aligned}$} & - \\
\hline & - \\
\hline Test for mucilage ( Ruthenium red test) & + \\
\hline Test for reducing sugar (Felhing's test) & + \\
\hline Test for chlorides( silver nitrate test) & - \\
\hline Test for sulphates (barium chloride test) & - \\
\hline Test for starch (added iodine) & - \\
\hline Test for flavonoid Shinoda test & - \\
\hline Alkaline reagent test & - \\
\hline
\end{tabular}

Table 6: phytochemical characterization of extracted polymer from $A$. Zapotilla.

\section{Viscosity}

The viscosity of freshly prepared $1 \% \mathrm{w} / \mathrm{v}$ solution of biomaterial was determined using Brookfield viscometer $^{12}$. The resulted values are mentioned in Table 1.

Table 7: Micro-elemental analysis of $\boldsymbol{A}$. zapotilla biomaterial.

\begin{tabular}{lc}
\hline \multicolumn{1}{c}{ Element } & \% Composition \\
\hline Carbon & 36.95 \\
Nitrogen & 0.56 \\
Hydrogen & 9.14 \\
\hline
\end{tabular}

\section{Ash Values}

Ash values such as total ash, acid insoluble ash and water-soluble ash were determined according to Indian Pharmacopoeia. The following procedures were used for determination of ash values (Table 5).

Table 8: Interpretation of IR peaks.

\begin{tabular}{lc}
\hline $\begin{array}{l}\text { IR peaks }\left(\mathbf{c m}^{-1}\right) \\
(\text { A. zapotilla })\end{array}$ & Interpretation \\
\hline 1012.66 & C-H Bending \\
1246.06 & C-O Stretching \\
1735.99 & C=O Stretching \\
2742.87 & $\mathrm{CH}_{2}$ C-H Stretching \\
2875.96 & Alkyl C-H Stretching \\
2933.83 & Alkyl C-H Stretching \\
3400 & O-H (Alcohol) \\
& Stretching(broad) \\
\hline
\end{tabular}




\section{Total Ash}

Total ash value was determined by taking three grams of biomaterial in a silica crucible The biomaterial powder was spread as a fine, even layer on the bottom of the crucible and ignited by gradually increasing the temperature to $55^{\circ} \mathrm{C}$ until it is white, indicating the absence of carbon. The crucible was cooled in a desiccator and weighed. The procedure was repeated to get constant weight. The percentage of total ash was calculated with reference to air dried sample ${ }^{12}$.

\section{Acid Insoluble Ash}

The ash obtained as described above was boiled with $25 \mathrm{ml}$ of dilute Hydrochloric acid for five minutes and filtered through an ash less filter paper. The insoluble ash was transferred into a silica crucible, ignited and weighed. The procedure was repeated to get a constant weight $^{13}$. The percentage of acid insoluble ash was calculated.

\section{Water-soluble Ash}

The total ash obtained as described above was boiled for $5 \mathrm{~min}$ with $25 \mathrm{ml}$ of water and filtered through an ash less filter paper. The insoluble ash was transferred into a silica crucible, ignited for $15 \mathrm{~min}$, and weighed a. The procedure was repeated to get a constant weight. The weight of insoluble matter was subtracted from the weight of the total ash. The difference of weight was considered as water soluble ash. The percentage of water-soluble ash was calculated ${ }^{13}$ (Table 5). Preliminary Phytochemical Screening of Isolated biomaterial

Aqueous solution of extracted biomaterial was used for phytochemical characterization. Test for carbohydrates, proteins, mucilage, alkaloids, fats, tannins amino acids, gums and polyphenols were perform according to standard procedure mentioned in literatures ${ }^{13-15}$.

Analytical evaluation of biomaterial Elemental analysis

Elemental analysis of carbon, hydrogen and nitrogen was carried using a Leco CHN-2000 determinator. A Perkin-Elmer Elemental Analyzer was used for the determination of oxygen ${ }^{16}$ (Table 7).

\section{Differential Scanning Calorimetry (DSC)}

DSC curve of A. zapotilla was obtained by a Differential Scanning Calorimeter at heating rate of $10^{\circ} \mathrm{C} / \mathrm{min}$ from 30 to $300^{\circ} \mathrm{C}$ in nitrogen atmosphere $(30 \mathrm{ml} / \mathrm{min})^{17}$ (Figure 2).

Table 9: Mucoadhesive property determined by shear stress method.

\begin{tabular}{|c|c|c|c|c|c|c|c|}
\hline \multirow[t]{2}{*}{ Polymer } & \multirow[t]{2}{*}{$\begin{array}{c}\text { Concentration } \\
\% \mathrm{w} / \mathbf{v}\end{array}$} & \multicolumn{6}{|c|}{$\begin{array}{c}\text { Weight required to detach glass plate }(\mathrm{gm}) \\
\text { At the time interval }(\mathrm{n}=3)\end{array}$} \\
\hline & & $5 \mathrm{~min}$ & $10 \mathrm{~min}$ & $15 \mathrm{~min}$ & $20 \mathrm{~min}$ & $25 \mathrm{~min}$ & $30 \mathrm{~min}$ \\
\hline \multirow[t]{5}{*}{ Isolated Biomaterial } & $1 \%$ & 7.3 & 9.6 & 12.8 & 16.2 & 23.5 & 29.8 \\
\hline & $2 \%$ & 13.5 & 18.1 & 24.3 & 29.8 & 36.6 & 48.2 \\
\hline & $3 \%$ & 21.2 & 27.8 & 34.7 & 38.1 & 47.3 & 58.9 \\
\hline & $4 \%$ & 33.7 & 41.2 & 48.6 & 56.7 & 65.3 & 86.4 \\
\hline & $5 \%$ & 44.6 & 53.7 & 67.8 & 87.6 & 114.5 & 154.4 \\
\hline HPMC & $3 \%$ & 58.3 & 65.1 & 73.7 & 95.2 & 112.3 & 152.8 \\
\hline $\mathrm{NaCMC}$ & $3 \%$ & 54.7 & 61.4 & 73.9 & 97.6 & 116.7 & 154.8 \\
\hline
\end{tabular}

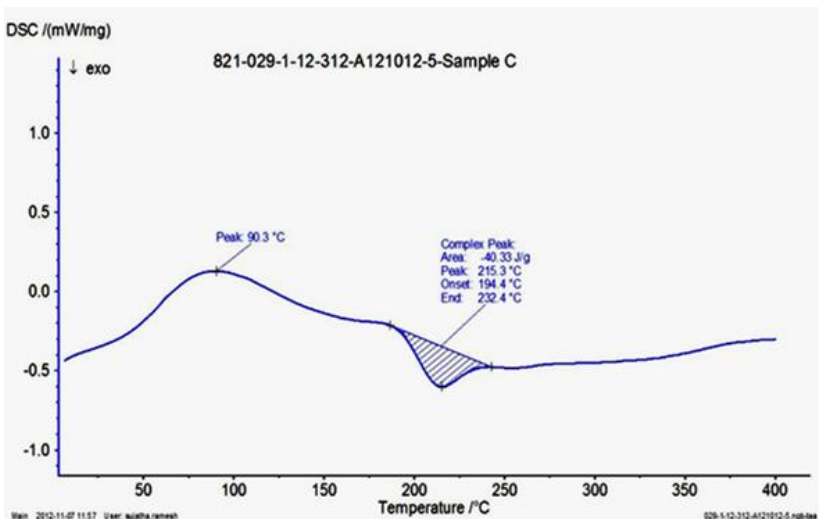

Figure 2: Graphical representation of differential scanning calorimetry.

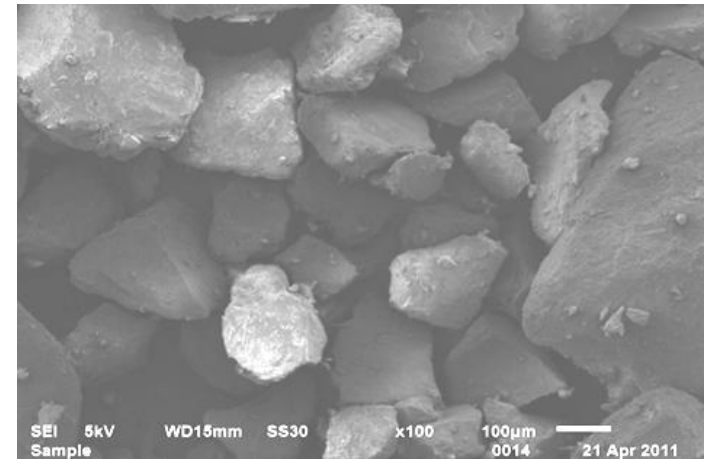

Figure 3: Surface characteristics by scanning electron microscopy (SEM). 


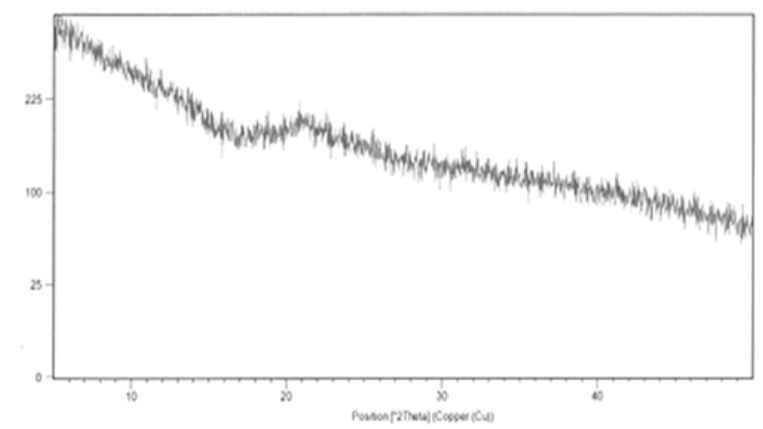

Figure 4: X-ray Diffraction of the biomaterial.

Table 10: Falling sphere analysis of polymer.

\begin{tabular}{lcc}
\hline Polymer & Concentration & $\begin{array}{c}\text { Average time }(\mathbf{s e c}) \\
\text { taken }(\mathbf{n}=\mathbf{3})\end{array}$ \\
\hline Isolated & $1 \%$ & 10.33 \\
Biomaterial & $2 \%$ & 28.21 \\
& $3 \%$ & 33.88 \\
& $4 \%$ & 43.69 \\
& $5 \%$ & 56.22 \\
\hline HPMC & $3 \%$ & 32.33 \\
NaCMC & $3 \%$ & 32.12 \\
\hline
\end{tabular}

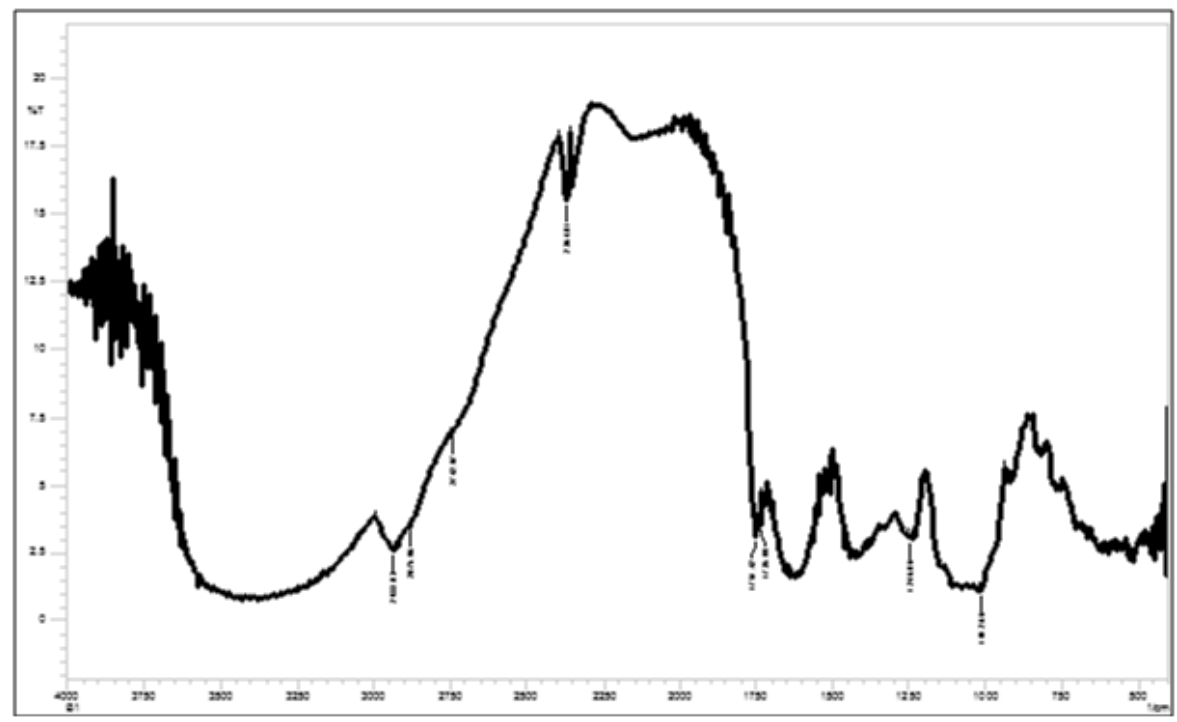

Figure 5: FTIR graph of the biomaterial.

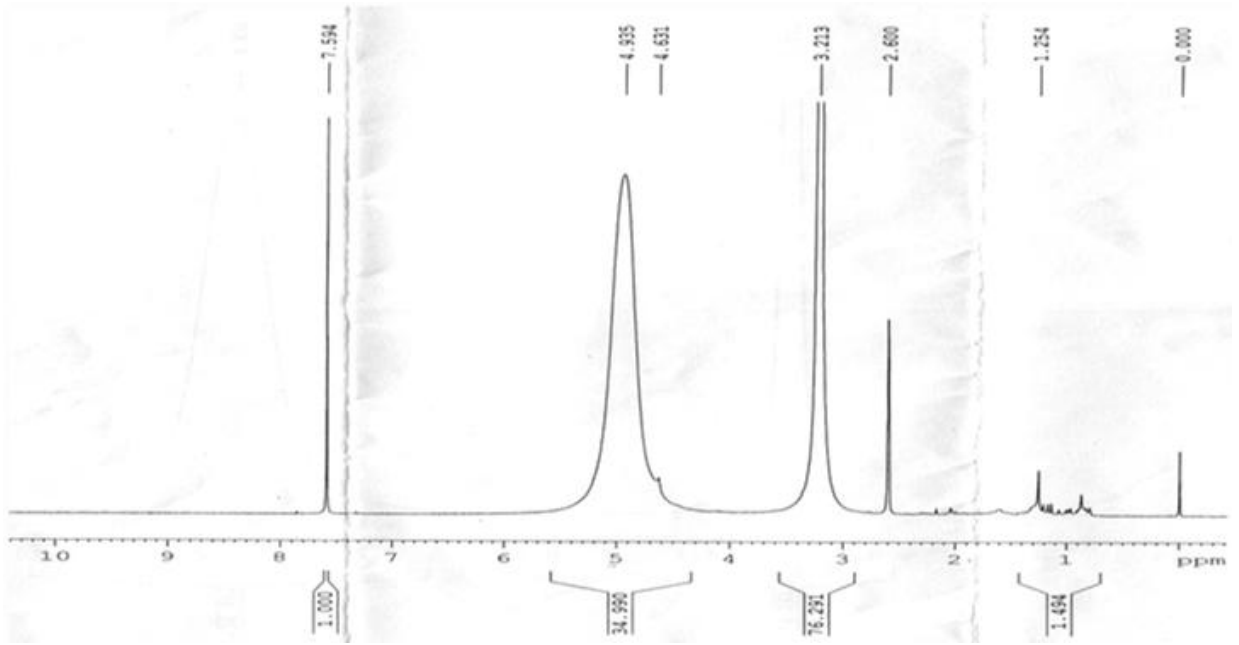

Figure 6: NMR spectra of the biomaterial. 


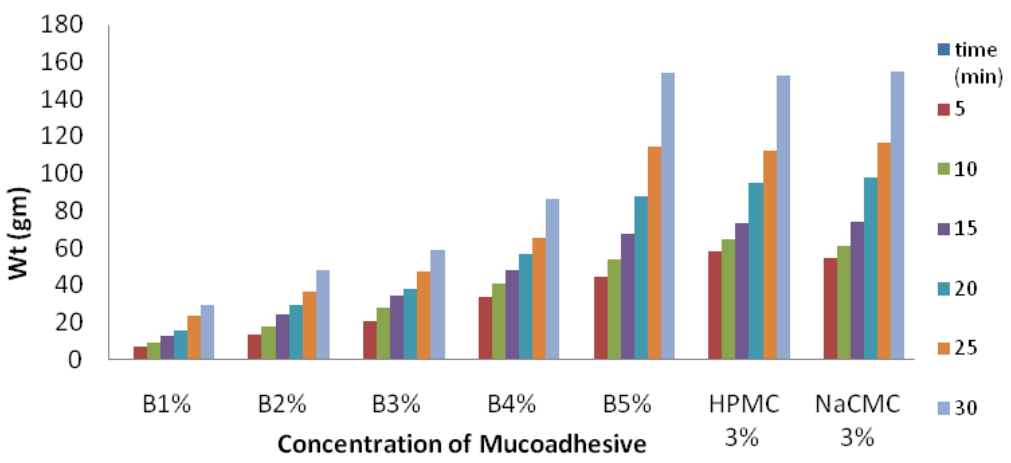

Figure 7: Graphical representation of shear stress study.

Surface Characteristics by Scanning Electron Microscopy (SEM)

The SEM photograph of dried isolated biomaterial (powdered sample) was obtained by Scanning Electron Microscope (Jeol, JSM-840A, Japan) with $20 \mathrm{Kv}$ accelerating voltage (Figure 3 ).

Table 11: Dislodgement time determine by rotating basket method in nasal mucosa.

\begin{tabular}{lc}
\hline Polymer & $\begin{array}{l}\text { Dislodgement } \\
\text { time (min) }\end{array}$ \\
\hline $\begin{array}{l}\text { A. zapotilla } \\
\text { biomaterial }\end{array}$ & 95 \\
\hline $\mathrm{HPMC}$ & 105 \\
\hline $\mathrm{NaCMC}$ & 90 \\
\hline
\end{tabular}

\section{PXRD Pattern}

Diffraction pattern of powdered sample was recorded with an X-ray diffractometer. X-ray diffraction was performed at room temperature $(25 \circ \mathrm{oC})$ with a diffractometer; target, $\mathrm{Cu}(\lambda=1.54 \AA)$, filter, $\mathrm{Ni}$; Voltage, $45 \mathrm{kV}$; current $40 \mathrm{~mA}$; time constant $10 \mathrm{~mm} / \mathrm{s}$; scanning rate $2^{0} / \mathrm{min}$; measured from $10-35^{0}$ at full scale 200 (Figure 4).

\section{FTIR study}

The FTIR spectrum of the sample was recorded using a FTIR spectrometer (Perkin Elmer1600, USA), using potassium bromide $(\mathrm{KBr})$ disc prepared from powdered samples mixed with dry $\mathrm{KBr}$ in the ratio $1: 200^{18}$. It was scanned from 4000 to $400 \mathrm{~cm}^{-1}$. Triplicate measurements were made and the spectrum with the clearest identifiable peaks was chosen (Figure 5 and Table 7).

\section{NMR Spectrum of Manilkara Zapota Polymer}

NMR spectra of $1 \mathrm{H}$ and $13 \mathrm{C}$ of mucilage was recorded using NMR (400 MHz) spectrometer (Bruker Avance II 400 NMR Spectrophotometer) ${ }^{19}$.

Acute toxicity study

Acute toxicity study was performed according to the Organization for Economic Cooperation Development (OECD) guidelines No 425 (OECD guidelines, 2008). The study protocol was approved by the Institutional Animal Ethical Committee (Registration No 1452/PO/a/11/CPCSEA). Animals were randomly distributed into two groups, each group comprising five animals. Group I consisted of control animals that received equivalent volume of water as vehicle. Group II animals received test dose of $2000 \mathrm{mg} / \mathrm{kg}$ body weight the rats were fasted overnight and were then administrated with freshly prepared solution of biomaterials in water. A test dose of $2000 \mathrm{mg} / \mathrm{kg}$ body weight was used. Five rats of both sex will be taken to perform acute oral toxicity studies. biomaterials was dissolve in water give per oral to overnight fasted rats and animal will be observed for the sign of acute toxicity for a period of 14 days by observing changes in the skin, corneal reflex, respiratory rate, autonomic symptoms, salivation, diarrhoea, lethargy, sleep, behavioral patterns, and convulsions and compared with the control group animals ${ }^{20,21}$

\section{Assessment of mucoadhesive properties}

Shear stress measurement

The mucoadhesive property of biomaterial was determined in vitro by shear stress method, ex-vivo by Park and Robinson method and rotating basket method. the shear stress measure the force that cause a mucoadhesive to slide with respect to the mucus layer in parallel to their place of contact of adhesion. The test was performed by using different concentration of mucoadhesive solution ranging from 1 to $5 \%$. A specified amount of solution was subjected for measuring the weight required for bond breaking at various contact intervals that is 5, 10, 15, 20, 25 and 30 minutes. Similar procedure was employed for HPMC and sodium CMC polymers ${ }^{22}$ (Table 8 and Figure 8 ).

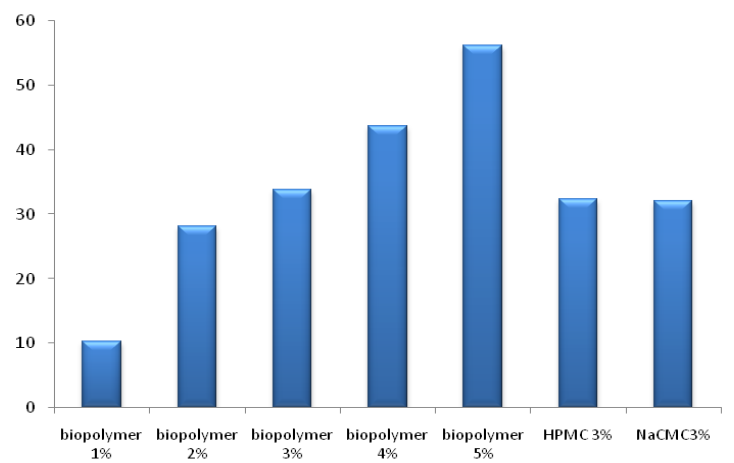

Figure 8: Graphical representation of falling sphere method.

Falling Sphere method

Falling sphere method was studied to determine mucoadhesive strength in terms of time in second required for mucoadhesive agent coated grain to fall 50 divisions in the burette filled with $10 \%$ mucus solution. Mustard grains which retained on sieve no 12 were taken and dipped in isolated biomaterial, HPMC and $\mathrm{NaCMC}$ solution of various concentration, 1.0, 2.0 and $3 \% \mathrm{w} / \mathrm{v}$ respectively. Grains were dried at $30^{\circ} \mathrm{C}$ and 
then each grains were slowly placed at the top layer of $10 \%$ mucus solution in the burette. Time taken by the grains to fall 50 divisions in the burette was noted and values were tabulated ${ }^{23,24}$ (Table 9 and Figure 9).

\section{Rotating cylinder method}

In this method the mucoadhesive property was evaluated by nasal mucosa. The biomaterial film was prepared by solvent casting method. The nasal mucosa was paced around rotating basket and the prepared film was adhered on this labial mucosa. It was allowed for rotation at $100 \mathrm{rpm}$. The detachment time of film from mucosal substrate was noted at regular intervals and data was compared with standard film of HPMC and sodium CMC polymer ${ }^{25}$.

\section{RESULTS AND DISCUSSION}

The percentage yield of biomaterial obtained from the fruit pulp of A. zapotilla was found to be $39 \%$ (w/w). The isolated biomaterial was subjected for various physicochemical tests like $\mathrm{pH}$, swelling index, bulk and tapped density, carr's index and Hausner's ratio, angle of repose, \%LOD and viscosity. Swelling index of the A. zapotilla biomaterial was found to be $19 \pm 0.23 \%$. High value of swelling index shows the high swelling ability of biomaterial. The swelling ability of any biomaterial depends upon its water retention capacity or water absorption capacity. The biomaterial was characterized by various organoleptic properties such as colour, odour, taste, shape, appearance and nature as shown Table 2. The solubility behaviour of the biomaterial indicates that it is quickly soluble and forms viscous colloidal solution in warm water, sparingly soluble in cold water, whereas insoluble in ethanol, methanol, acetone, Cyclohexane, Chloroform, Benzene and ether. The particle size distribution of biomaterial was determined and their data are tabulated (Table 4 and Figure 1). The purity of biomaterial was determined by prescribed phytochemical tests, which indicated the absence of alkaloids, steroids, flavonoids, tannins and phenols. Only carbohydrates saponins and mucilage were found to be present, which confirms the purity. From the Elemental analysis it was found that the A. zapotilla biomaterial have high carbon hydrogen ratio. Differential Scanning Calorimetry (DSC) measures the heat loss or gain, resulting from physical or chemical changes within a sample as a function of temperature. A sharp symmetric melting endotherm can indicate relative purity, whereas broad asymmetric curve suggests impurities or more than one thermal process. The endothermic peak usually indicates the loss of water present in the compound. The DSC curve of A. zapotilla showed two broad endothermic peaks at temperature $90.3^{\circ} \mathrm{C}$ and $215.3^{\circ} \mathrm{C}$. The SEM photographs of A. zapotilla biomaterial (Figure 3 ) have revealed that the shape of the biomaterial was found to be irregular.

The X-ray diffraction pattern of biomaterial obtained from A. zapotilla (Figure 4) did not show any characteristic peak, which indicates amorphous nature. IR spectroscopy is a useful tool in identification as well as purity of a compound. The principal absorption peaks of biomaterial was interpreted (Figure 5) and data are tabulated in Table 8 .

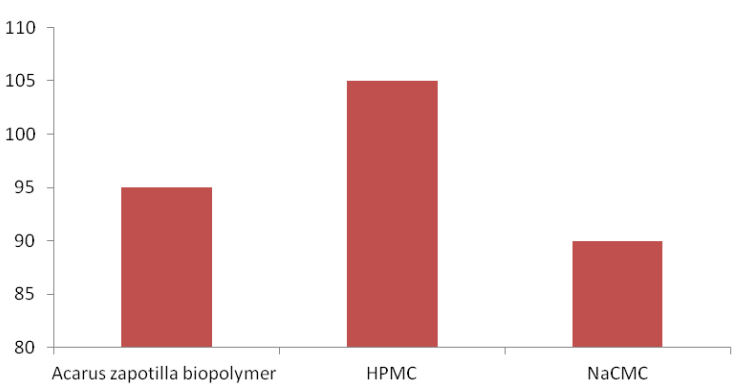

Figure 9: Graphical representation of dislodgement time determine by rotating cylinder method in nasal mucosa.

\section{NMR Study}

$1 \mathrm{H}$ NMR of $A$. zapotilla biomaterial showed chemical shift at $\delta 1.2 \mathrm{ppm}(-\mathrm{C} \equiv \mathrm{CH}$, acetylenic proton), $2.5 \mathrm{ppm}$ (- $\mathrm{C} \equiv \mathrm{CH}$, acetylenic proton), $\delta 3.2-4.6 \mathrm{ppm}\left(-\mathrm{CH}_{3} \mathrm{OR}\right.$, ether) proton), $\delta 4.6 \mathrm{ppm}$ (-C=CH, vinylic proton), $\delta 4.9$ ppm (R-OH, hydroxyl proton) and $\delta 7.5 \mathrm{ppm}(\mathrm{Ar}-\mathrm{H}$, aromatic proton) (Figure 6).

In acute toxicity studies, the test animals did not reveal any significant change in their body weight, corneal reflex, respiratory rate and autonomic symptoms. No skin reaction, salivation diarrhea, lethargic conditions, sleeping conditions and convulsions were observed on the animals. So it clearly revealed that biomaterial was non toxic in nature. A. zapotilla biomaterial (5\%) showed shear stress value $154 \mathrm{gm}$ after 30 minutes, which was comparable to HPMC $3 \%$ and Sodium CMC $3 \%$ solution. In falling sphere method the coated mustard grains of size 1.0 to $1.1 \mathrm{~mm}$ were allowed to move top to bottom in $50 \mathrm{ml}$ burette containing $10 \%$ mucus solution. Mucoadhesion time was determined and compared with standard Figure 8. From the study it was found that the isolated mucoadhesive agent was shown comparable mucoadhesion as compared to the standard. A. zapotilla biomaterial showed dislodgement time 95 minutes from nasal mucosal substrate of goat, which was more than sodium CMC (90 minutes) and less than HPMC (105 minutes) Figure 7. These results suggested that $A$. zapotilla biomaterial possessed an appreciable mucoadhesive property.

\section{CONCLUSION}

In the present study the biomaterial was successfully isolated from A. zapotilla with a good percentage yield by a simple economic process. The isolated biomaterial shows promising inbuilt mucoadhesion property when compared against HPMC and NaCMC. It is also confirmed by presence of hydroxyl and carbonyl functional groups in FTIR spectrum which are responsible for mucoadhesion. Hence conclusion was drawn that it can serve as a potential excipient for formulating transmucosal drug delivery systems. Since this natural mucoadhesive agent is edible, it is easily biodegradable and may provide an alternative to 
conventional synthetic/ semisynthetic mucoadhesive agents.

\section{ACKNOWLEDGEMENTS}

The authors extend their thanks and appreciation to the Devsthli Vidyapeeth College of Pharmacy, Rudrapur, Uttarakhand, India to provide necessary facilities for this work.

\section{AUTHOR'S CONTRIBUTION}

The manuscript was carried out, written, and approved in collaboration with all authors.

\section{CONFLICT OF INTEREST}

No conflict of interest associated with this work.

\section{REFERENCES}

1. Singh AV. Biopolymers in drug delivery. Pharmacologyonline 2011; 1: 666-674

2. Gandhi RB, Robinson JB. Bioadhesion in drug delivery systems. Medical process through technology 1989; 15:21-46.https://doi.org/10.1016/B978-0-12-8097175.00012-9

3. Madsen F, Eberth K, Smart J. A rehological assessment of the nature of interactions between mucoadhesive polymers and a homogenized mucus gel. Biomaterials 1998; 19: 1083-1092. https://doi.org/10.1016/s0142-9612(98)00037-4

4. Mathiowitz E, Chickering D, Jacob JS, Santos C. In: Mathiowitz E (eds.) Encyclopedia of controlled drug delivery, Vol. 1, New York; John Willey and Sons 1999; 9-44.

5. Mistry S, Biswal PK, Mishra B, Sahoo S. Isolation, Characterization and Pharmaceutical evaluation of the mucilage from Polyalthia suberosa leaves. Int J Pharm Tech Res 2010; 2: 1455-1459.

6. Ojha A, Satheesh Madhav NV. Isolation and characterization of novel mucoadhesive biomaterial from Phoenix dactylifera. Int Curr Pharm J 2012; 1(8): 205-208.

7. Ramu G, Krishna Mohan G, Jayaveera KN, Preliminary investigation of Patchapassali mucilage (Basella alba) as tablet binder. Int J Green Pharm 2011, 5(1), 24-27. https://doi.org/10.4103/0973-8258.82091

8. Indian Pharmacopeia, Ministry of Health and family welfare, Government of India, Controller of Publications, New Delhi 1996; A-54.
9. Anonymous, Quality control methods for medicinal plant materials, World Health Organization, Geneva 2002; 8 (28): 45-46.

10. Anonymous, The Ayurvedic pharmacopoeia of India, $1^{\text {st }}$ edition, Ministry of Health and Family Welfare, Government of India 2001; 1(3): 29-31.

11. Bharadia PD, et al. A preliminary investigation on sesbania gum as pharmaceutical excipients. Int $\mathbf{J}$ Pharm Excip 2004; 1(4): 102-105.

12. Sink PJ, Martins. Physical pharmacy and pharmaceutical sciences, $5^{\text {th }}$ Edition, B.I publications Pvt. Ltd, New Delhi, 2006; 553-556.

13. Lala PK. Practical Pharmacognosy. Lina Guha Publication: India; 1981.

14. Kokate CK. Practical Pharmacognosy, $3^{\text {rd }}$ ed. New Delhi, India,Vallabh Prakashan, 1991.

15. Gupta MK. Textbook of Natural Products, Volume IV, $1^{\text {st }}$ ed., Meerut; Pragati Prakashan: 2009.

16. Silverstein RM, Webster FX. Spectroscopic identification of organic compounds, $6^{\text {th }}$ ed., New Delhi; Wiley India Pvt. Ltd: 2010.

17. Sharma Y R et al. Elementary organic spectroscopy, principles and chemical applications, S Chand and Co. Ltd, New Delhi. 2010, 89-150.

18. Kalsi PS. Spectroscopy of Organic Compounds. New Age International Publishers, $6^{\text {th }}$ ed. 2007; 65-183.

19. Beckett $\mathrm{AH}$ and Stenlake JB: Practical pharmaceutical chemistry, Part II. CBS Publishers, Delhi, $4^{\text {th }}$ ed. 2004; 7275.

20. OECD 423 guideline for testing of chemicals acute oral toxicity-acute oral class method. 2001

21. Satheesh Madhav NV, Uma Shankar MS. (A novel smart mucoadhesive biomaterial from Lallimantia royalena seed coat). Sci Asia 2011; 37: 69-71. https://doi.org/10.2306/scienceasia15131874.2011.37.069

22. Peh KK, Wong CF. Polymeric film as vehicle for buccal drug delivery: mechanical and bioadhesive properties. J Pharm Pharmaceutics Sci 1998; 2:53-61.

23. Teng CL, Ho NF. Mechanistic studies in the simultaneous flow and adsorption of polymer coated latex particles on intestinal mucus-I methods and physical model development. J Cont Rel 1987; 6: 133-149. https://doi.org/10.1016/0168-3659(87)90071-X

24. Ranga Rao KV, Buri P. A novel in situ method to test polymers and coated micro particles for bioadhesion. Int $\mathrm{J}$ Pharm 1989; 52: 265-70 https://doi.org/10.1016/0378-5173(89)90229-9

25. Satheesh Madhav NV, Yadav AP. A novel translabial platform utilizing bioexcipients from Litchi chinesis for the delivery of rosiglitazone maleate. Acta Pharmaceutica Sinica B 2013; 3(6): 408-15.

https://doi.org/10.1016/j.apsb.2013.10.004 